\title{
Być kobietą czy być rośliną? O formach podmiotowości w Wegetariance Han Kang
}

Zofia Jakubowicz-Prokop

TEKSTY DRUGIE 2018, NR 2, S. 206-220

DOI: $10.18318 /$ td.2018.2.13

Moje organy wewnętrzne zanikają, prawda? Nie jestem już zwierzęciem. Nie potrzebuję jedzenia, aby żyć. Wystarczą mi promienie słońca. ${ }^{1}$

\section{Ucieczka w roślinę - czyli jak być poza byciem?}

Pytanie o roślinę, jej ontologiczny status i sposób bycia z perspektywy tradycyjnej metafizyki może wydać się bezpodstawne, jeśli jednak przyjmiemy punkt widzenia postmetafizyczny, kierując swoją uwagę na wszystkie rodzące się ontologie wielości, zrozumiemy, że pytanie o to, czym - czy raczej jak - jest roślina, w rzeczywistości pozwoli nam na skonstruowanie filozoficznych i antropologicznych koncepcji, które będą bardziej krytyczne, etyczne, świadome i otwarte na innego. Żeby jednak zacząć, należy zwrócić się w stronę narracji i bytów, które były przez zachodnią myśl marginalizowane lub

\section{Zofia Jakubowicz- \\ -Prokop - \\ ur. 1993, studentka studiów magister- skich w Instytucie Kultury Polskiej oraz W Instytucie Filozofii na UW. Zajmuje się antropologią słowa i estetyką, bada obec- ność zwierząt i roślin w prozie i filozofii.}

1 H. Kang Wegetarianka, przeł. J. Najbar-Miller i Ch. Jeong In, Kwiaty Orientu, Skarżysko-Kamienna 2014, s. 139. 
ignorowane. Roślina w tradycji metafizycznej często, jeśli w ogóle, przedstawiana była jako coś gorszego, niepełnego, „niekompletnego”. Ale właśnie dzięki takiemu statusowi może się ona stać bytem rewolucyjnym, który jak pisze Michael Marder, dzięki swojemu wykluczeniu z tradycji filozoficznej, zyskuje „kluczową rolę w bieżącym przewartościowywaniu metafizycznego systemu wartości"2.

W niniejszym artykule sięgam po feministyczną powieść Wegetarianka koreańskiej pisarki Han Kang, wierząc, że w niektórych przypadkach literatura może nauczyć nas więcej o emancypacyjnych i mniejszościowych sposobach bycia niż praca filozoficzna. Czytelniczka w pierwszej chwili może poczuć się rozczarowana tym wyborem - Wegetarianka opowiada bowiem o kobiecie, która pod wpływem snu porzuca dotychczasową egzystencję i, koniec końców, zostaje zamknięta w szpitalu psychiatrycznym. Bohaterka powieści nie zamienia się $\mathrm{w}$ roślinę $\mathrm{n}$ a $\mathrm{p} \mathrm{r}$ a w d ę, jeśli jednak sięgniemy do wykładni Deleuze'a i Guattariego ${ }^{3}$ i potraktujemy opowieść o Yong-hye jako historię stawania-się-rośliną - czy raczej bycia-rośliną, ponieważ przemiana kobiety jest bardziej trwała i ostateczna - dostrzeżemy, że to, co nie daje się ująć w realistycznym przedstawieniu, może w rzeczywistości dziać się gdzieś obok, mimochodem, stawać się na naszych oczach. Dlatego należy zadać sobie pytanie, jak zmienia się sposób bycia bohaterki Wegetarianki, a nie czy rzeczywiście zmienia się ona w roślinę. Jeśli będziemy pamiętać o Tysiącu plateau, będziemy również wiedzieć, że stawanie-się-rośliną nie oznacza praktycznej zmiany w roślinę, ale zmianę w trybie funkcjonowania. Stawanie-się-rośliną jest rzeczywiste, chociaż roślina, którą się stajemy, nie jest $t^{4}$.

2 M. Marder Plant-Thinking. A Philosophy of Vegetal Life, Columbia University Press, New York 2013, s. 55 .

3 Deleuze i Guattari w Tysiq̨cu plateau zwracali uwagę przede wszystkim na stawanie-się-zwierzęciem, ale stawanie-się-rośliną wydaje się równie, albo nawet bardziej trafne ze względu na radykalnie mniejszościowy charakter rośliny, która w tradycji metafizycznej często, jeśli w ogóle, przedstawiana była jako coś gorszego, niepełnego, "niekompletnego". Autorzy Tysiq̨c plateau tłumaczą pojęcie stawania się w następujący sposób: „Stawać się to wychodzić poza właściwe sobie formy, poza podmiot, którym się jest, poza posiadane organy albo funkcje, jakie się pełni, wydobyć cząstki między którymi ustanawia się stosunki ruchu oraz prędkości i spoczynku, najbliższe temu, czym się stajemy i poprzez co się stajemy"; G. Deleuze, F. Guattari Tysiq̨c plateau, Fundacja Bęc Zmiana, Warszawa 2015, s. 330.

4 "Stawanie się nie wytwarza niczego poza sobą. [...] Tym, co rzeczywiste, jest samo stawanie się, blok stawania się, a nie rzekomo stałe elementy tego stawania się", tamże, s. 288. 
Stosowanie teorii wyrosłych z zachodniej myśli akademickiej do analizy koreańskiej powieści powoduje oczywiście zasadniczy problem metodologiczny. W tym przypadku traktuję jednak Wegetariankę jako powieść, która mimo pochodzenia kulturowego stanowi równie inspirujący przykład "roślinnej” literatury dla europejskiej czytelniczki. Co więcej, chciałabym uniknąć idealizowania dalekowschodniej kultury jako radykalnie innej i niedostępnej, zwłaszcza że ukazana w książce społeczna rzeczywistość paradoksalnie pod wieloma względami wcale nie jest tak odległa od naszej, co pokazuje m.in. wykorzystywana przeze mnie praca Joanny Elfving-Hwang Representations of Femininity in Contemporary South Korean Women's Literature ${ }^{5}$.

\section{Koreanki i literatura}

Nie chcąc zagłębiać się w historyczno-kulturowe podłoże Wegetarianki, chciałabym zwrócić w tym miejscu uwagę na zaledwie parę istotnych wątków wyłaniających się z pracy Elfving-Hwang. Badaczka, analizując przedstawienia kobiet w powieściach kilku współczesnych koreańskich pisarek, pokazuje, że mimo oczywistych przemian, jakie przeszło koreańskie społeczeństwo w wyniku modernizacji i kapitalizacji, pozycja kobiety wciąż pozostaje w nim niezwykle ograniczona przez symbolikę, głęboko zanużoną w neokonfucjańskiej tradycji, która kojarzyła kobiecość z tym, co pasywne, negatywne i material$n e^{6}$. Co więcej, w przednowoczesnej Korei ściśle przestrzegano przypisanych płciom ról społecznych, które miały odzwierciedlać konfucjański dualizm i utrzymywać ład społeczny ${ }^{7}$. Według Elfving-Hwang w przednowoczesnej Korei kładziono szczególny nacisk na rygorystyczne przestrzeganie zasad rządzących życiem kobiet i ograniczanie ich wolności, ponieważ w przypadku tych, których bierność i stabilność stanowiła podłoże dla aktywnych ojców, mężów i synów, wszelkie odejście od przypisanej pozycji mogło okazać się

5 J. Elfving-Hwang Representations of Feminity in Contemporary South Korean Women's Literature, Global Oriental, 2010. Elfving-Hwang analizuje przede wszystkim prozę pisaną przez kobiety w latach 90., tylko pokrótce odnosząc się do tego, co działo się w literaturze później. Powieść Han Kang jest powieścią znacznie późniejszą, opublikowaną w 2007 roku, wydaje się jednak, że podstawowe problemy zarysowane przez badaczkę znajdują swoje odzwierciedlenie także w Wegetariance.

6 Tamże, s. 17.

7 Tamże. 
poważnym zagrożeniem nawet dla pokoju ${ }^{8}$. W efekcie tym bardziej istotne stało się trzymanie kobiet w domu. Wyobrażenie o prawdziwej i cnotliwej kobiecie, jak pisze badaczka, było ściśle związane z tym, co wewnątrz - jej zadania i zainteresowania musiały więc ograniczać się do wypełniania domowych i matczynych obowiązków ${ }^{9}$, a każde przekroczenie tej granicy postrzegane było jako potencjalne zagrożenie dla społeczeństwa.

Jak ukazuje Elfving-Hwang, współczesna Koreanka być może ma większą realną swobodę, ale symbolicznie wciąż pozostaje uwikłana w strukturalne schematy, które uniemożliwiają jej zbudowanie własnej tożsamości i wyjście poza granicę przypisanego jej terytorium. Rola bohaterek w analizowanych przez badaczkę powieściach zostaje ograniczona do wymogów dobrej żony i matki, działalność sprowadzona do wypełniania domowych obowiązków, a seksualność zrównana z potrzebami mężczyzny ${ }^{10}$. Przeznaczona dla nich przestrzeń nie pozwala im w żadnym stopniu na samorealizację, ponieważ jest skonstruowana ${ }^{11}$ przede wszystkim w celu opieki nad pracującym mężem, zaspokajania jego potrzeb oraz wychowania dzieci, słowem - zapewniania stabilności rodzinie, a w dalszym rozrachunku społeczeństwu jako takiemu ${ }^{12}$.

\section{Wegetarianka - bycie-rośliną jako choroba}

Chociaż Wegetarianka jest dziełem późniejszym niż teksty badane przez Elfving-Hwang, również w tej powieści łatwo dostrzec ślady podobnych zmagań. Szczególnie widać to w pierwszej części, w której mąż bohaterki opowiada o początkach jej przemiany. Z jego narracji jasno wynika pragmatyczny, całkowicie pozbawiony romantyzmu stosunek do małżeństwa. Yong-hye zostaje przedstawiona jako przeciętna kobieta, pozbawiona charyzmy i zainteresowań, spokojna i małomówna, i w gruncie rzeczy - nijaka:

Zgodnie z moimi przewidywaniami bez zarzutu wypełniała rolę przeciętnej żony [...] Mówiła niewiele. Rzadko mnie o coś prosiła i nie wtrącała

8 Tamże, s. 20.

9 Jak pisze Elfving-Hwang, jeszcze do niedawna kobiety nazywano an saram, czyli ludźmi-wewnątrz, natomiast mężczyźni określani byli jako ludzie zewnętrzni - pakkat saram; tamże, s. 18.

10 Tamże, s. 83.

11 Zob. tamże, s. 86-87. 
się, kiedy wracałem do domu późną nocą. [...] A kiedy nadchodziła pora posiłku, otwierała drzwi i w milczeniu zabierała się do przygotowania czegoś do jedzenia. Trudno powiedzieć, by mieszkanie z taką osobą było szczególnie interesujące. ${ }^{13}$

Małżeństwo objawia się tu jako relacja bez relacji, związek dwóch wyalienowanych osób, które egzystują równolegle, dostarczając sobie potrzebnych do życia składników, tzn. mąż zapewnia pieniądze, a żona „domowe ciepło”; emocjonalne zbliżenie jest raczej niepotrzebną fanaberią. Okazuje się jednak, że utylitarystyczna sielanka Chonga ma termin ważności, kiedy Yong-hye przestaje pasować do swojej roli. Jej przemiana nie polega na tym, że oto Yong-hye staje się świadomą siebie kobietą, bierze los w swoje ręce i zaczyna sprzeciwiać się stawianym przed nią zadaniom dobrej żony - jest to raczej transformacja płynąca z wewnątrz ciała, nie ze świadomości, której kobieta nie miała przecież szansy zbudować; Yong-hye wciąż nie jest w stanie przekroczyć postawionych jej przez społeczeństwo granic, dlatego jej zmiana jest immanentna i zamiast być przyczynkiem do wykreowania nowej tożsamości, prowadzi do erupcji tej dotychczasowej, jakby była to jedyna możliwa forma ucieczki. Kiedy kobieta przestaje jeść i gotować mięso, coraz mniej mówi i nie zgadza się na seks z powodu męczących ją snów, mąż reaguje na to narastającą paniką, ponieważ to, co się dzieje, nie tylko pozbawia go kontroli, ale również wymyka się logice mieszczańskiego życia, którą kieruje się mężczyzna.

Monotonna opowieść męża w pierwszej części co jakiś czas jest przerywana przez narrację Yong-hye, która przez resztę książki będzie przede wszystkim milczeć. Relacjonowane przez nią sny są całkowitym odwróceniem panujących na jawie zasad. W tych fragmentach język Yong-hye jest bardziej intymny, surowy i chaotyczny niż ten, którym posługuje się w swojej opowieści jej mąż, ponieważ jej perspektywa stanowi radykalną alternatywę dla - racjonalnych, choć zarazem napędzanych fantazjami - narracji pozostałych bohaterów. W snach powracają ciągle te same motywy - mięso, krew, twarz, która jest zarazem znana i obca, strach i przemoc. To przestrzeń nieprzyjazna, w której transformacja objawia się jako proces trudny i bolesny. Sny stopniowo zaczynają rozsadzać struktury dotychczasowego życia Yong-hye, całkiem realnie je zmieniając. Do głosu dochodzi teraz jej ciało, które jest niewygodne, nieadekwatne i krwiste. Stanowi ono materialny naddatek, dla którego nie ma miejsca w sferze esencjalizmów, wyobrażeń i struktur społecznych. 
A przy tym Yong-hye wcale nie traci kontroli nad własnym życiem - właściwie nigdy jej nie miała. Teraz po prostu zmienia się rytm jej życia, przestaje być Yong-hye, ucieleśnionym wyobrażeniem na temat idealnej żony, a staje się kobietą-organizmem, który ma swoje potrzeby, często sprzeczne z tym, czego się od niego oczekuje.

Zderzenie logiki rozsądku z logiką snu jest tu kluczowe. Zdroworozsądkowa rzeczywistość to ta, w której wszystko zostaje sprowadzone do prostych wzorów zachowań i ma swoje miejsce w świecie społecznym, rządzonym prawem praktyczności. Natomiast logika snu jest logiką bez logiki, swoistym buntem realnego, które przebija się przez płaszczyznę ustandaryzowanych wyobrażeń i doprowadza ją powoli do rozpadu. Dzięki temu zabiegowi Han Kang udaje się pokazać świat społeczny jako papierowy, fantazyjny i, koniec końców, bardziej idealistyczny niż świat senny, w którym wszystkie tłumione instynkty, potrzeby i funkcje organizmu wychodzą na wierzch. Yong-hye pod wpływem snów stopniowo przestaje być zdolna do funkcjonowania w dotychczasowym trybie, co wbrew pozorom nie oznacza jej porażki - pokazuje to jednak, jak wypracowane społecznie formy podmiotowości nie przystają do realnie żyjących jednostek. Okazuje się przy tym, że każde z działań, które podejmuje, by wyzwolić się z opresji, czyni ją zarazem coraz mniej ludzką. Wegetarianizm jest przecież „niezgodny z instynktem. Jest przeciwny naturze"14, ponieważ mięso to znak ludzkiej dominacji nad naturą, oznaka cywilizacji, podobnie jak język, który przecież jest zarazem na wskroś męskocentryczny, gdyż od zarania dziejów służył mężczyznom u władzy do strukturyzowania świata zgodnie z ich perspektywą. Być może niejedzenie mięsa jest walką z męską opresją, ze społeczną rolą kobiety i symboliką kobiecości, ale jest również pierwszym krokiem ku odrzuceniu tego, co ludzkie. „Czy jednak da się żyć bez mięsa?", pyta żona prezesa Chonga, co czytelniczce, która być może sama jest wegetarianką, może wydać się pytaniem absurdalnym, ale w rzeczywistości powieści Han Kang wcale nie jest, co więcej, odpowiedź na nie jest przecząca - nie, nie da się, przynajmniej nie, jeśli jest się żoną, córką, kochanką.

Zachowanie Yong-hye okazuje się tak niezrozumiałe dla jej otoczenia, że wywołuje kolejno strach, przemoc i odrzucenie. Chong coraz częściej traci cierpliwość, aż w końcu, kiedy jego żona wciąż odmawia mu swojego ciała, zaczyna ją gwałcić. Ojciec, wściekły na córkę i jej fanaberie, również dopuszcza się na niej przemocy. Kiedy wszelkie formy perswazji zawodzą, a jej 
wegetarianizm nie okazuje się ani modą, ani fanaberią, oczywistą konkluzją wydaje się choroba psychiczna. Przypuszczenia te zostają potwierdzone, kiedy podczas rodzinnego obiadu Yong-hye podcina sobie żyły. Rzecz w tym, że to, co dla jej otoczenia jest jawnym dowodem zaburzenia, dla Yong-hye jest kolejną rozpaczliwą próbą sprzeciwienia się wszechogarniającej opresji $1^{15}$.

\section{Mongolska plamka - bycie-rośliną jako metafora}

Do tej pory rośliny pojawiają się w powieści zaledwie mimochodem, w snach i w pożywieniu, ale wciąż są raczej dekoracyjnym tłem dla Yong-hye, która dopiero zwraca się w stronę natury, wciąż jednak jako ludzki podmiot. Transgresja kobiety wiąże się z tym, co organiczne czy naturalne, wydarza się raczej zgodnie z jej ciałem niż wolą. Mówienie o ciele Yong-hye jest jednakże problematyczne, zwłaszcza w części pierwszej, w której oczywiście daje się powiązać niejedzenie mięsa i bezsenność z problemami cielesnymi, zmiana bohaterki zostaje nam jednak przedstawiona głównie poprzez jej sny i wspomnienia, coś, co przywykliśmy przypisywać funkcjom umysłowym. Dlatego tak ważne wydaje mi się mówienie o Yong-hye w kategoriach organizmu, w którym akty fizyczne i psychiczne są ze sobą na tyle splecione, że nie ma sensu ich sztucznie rozdzielać. Dzięki temu łatwiej uchwycić przemianę Yong-hye jako zmianę sposobu bycia, przejście z bytu ludzkiego do organicznego, wegetatywnego bycia, które ukazuje, jak sztuczne i w gruncie rzeczy szkodliwe może być rozdzielanie ciała i umysłu.

Rośliny jako takie pojawiają się dopiero w części drugiej, Mongolskiej plamce, czyli historii bezimiennego męża In-hye. Szwagier Yong-hye jest zaangażowanym społecznie artystą, co tylko pozornie wskazuje na większą wrażliwość - jego życie rodzinne również jest pozbawione głębokich więzi i bliskości, nawet mimo obecności małego dziecka. Podobnie jak Chong skrycie fantazjuje o siostrze żony, tak mąż In-hye rozmyśla potajemnie o swojej szwagierce. Obaj mężczyźni dowodzą, że niezależnie od swojego pochodzenia i statusu społecznego, nawet jeśli światy ich fantazji są różne, w podobnym

Opowieści o kobietach, które cierpią na zaburzenia psychiczne z powodu patriarchalnej przemocy i społecznej izolacji, są czytelniczce pewnie dobrze znane i, jak wskazuje Elfving-Hwang, nie są również obce koreańskiej literaturze. Narracja o chorobie głównej bohaterki powraca do czytelniczki przez całą powieść, wydaje się jednak, że interpretacja zachowań Yong-hye jako przejawu choroby, zgodna zresztą z narracją Chonga, jest zbyt oczywista, by można ją tak łatwo przyjąć; zob. J. Elfving-Hwang Representations of Feminity..., s. 85-91. 
stopniu są wyalienowani zarówno z rzeczywistości, jak i z własnych pragnień. Mąż In-hye okazuje się tylko kolejnym uosobieniem opresyjnej męskości. W przeciwieństwie do Chonga traktuje on Yong-hye nie jako kobietę sprowadzoną do roli uległej żony, ale jako zestetyzowany obiekt seksualny.

Obsesja mężczyzny zaczyna się od mongolskiej plamki, małego zielonkawego znamienia na pośladkach głównej bohaterki, które z jakiegoś powodu nie zniknęło w dzieciństwie, tak jak powinno. Plamka w oczach szwagra staje się znakiem tajemnicy i wyjątkowości. Ta obsesja splata się w jego marzeniach z artystyczną wizją intymności i seksualności człowieka-rośliny. Pchany przez artystyczny impuls, mężczyzna doprowadza w końcu do zaangażowania Yong-hye w prace nad jego projektem, który opisuje m.in. tak:

To właśnie wówczas wyobraził sobie kwiat rozwierający się pomiędzy kobiecymi pośladkami. Fakt istnienia plamki mongolskiej na pośladkach szwagierki i scenę miłosnego aktu nagich pomalowanych w kwiaty ciał łączył trudny do pojęcia, aczkolwiek zupełnie dla niego oczywisty i logiczny związek przyczynowo-skutkowy. ${ }^{16}$

Połączenie nagich ludzkich ciał z sensualnym wyobrażeniem roślin stwarza pociągającą erotycznie i estetycznie wizję. To obraz niemożliwy, który wiąże dwie obce sobie seksualności, czyniąc z ludzi nie-ludzi, a z kwiatów nie-rośliny:

Scena miłosnego aktu rozgrywająca się w ciszy przypominającej próżnię. Zatopione w sobie kwieciste ciała kochanków, ich bezpruderyjne ruchy. Czasem gwałtowne, a czasem delikatne. Zbliżenie genitaliów. Wszystko ukazane na ekranie. Zupełnie otwarcie, ale to właśnie otwartość, ekstremalność tego obrazu staje się podstawą oczyszczenia. ${ }^{17}$

Plamka między pośladkami kobiety mówi do artysty o czymś pradawnym, niemal mistycznym, wzbudza zarazem erotyczny i estetyczny pociąg.

16 H. Kang Wegetarianka, s. 54.

Tamże, s. 85. Ekstremalność, o której mówi mąż In-hye, przypomina poniekąd bezpośredniość brutalnych nieraz opowieści Yong-hye z pierwszej części. Otwartość, która ukazuje rzeczy takimi, jakimi są, a nie takimi, jakimi chce je widzieć społeczeństwo, została zresztą dobrze oddana w atmosferze wokół artystycznego projektu mężczyzny. Artysta, który całe życie zajmował się sztuką społecznie zaangażowaną, nagle przy Mongolskiej plamce, jak nazywa swoje dzieło, zostaje oskarżony o bluźnierstwo, pornografię, dewiację, a wreszcie - szaleństwo. 
Mężczyzna maluje kwiaty na jej ciele, które są dla niego wyobrażeniem „efemerycznego piękna"18 obojętnej, pasywnej rośliny. Ostatecznie funkcją kwiatów okazuje się estetyzacja ciała, związanie go z fantazmatyczną wizją Natury i uczynienie z kobiety żywego symbolu własnej obsesji. W efekcie Yong-hye staje się pięknym obiektem seksualnym oraz, być może, sublimacją pragnienia o zjednoczeniu się z nieokiełznaną przyrodą.

Dla Kanta w Krytyce władzy sądzenia pojęcie piękna jest silnie związane ze stosunkiem człowieka do przyrody i z rozkoszą, którą w tej relacji odczuwa. Prawdziwe piękno nie jest według filozofa czymś, czego możemy doświadczyć empirycznie, ale stanowi efekt gry wyobraźni i intelektu; o pięknie danego przedmiotu decyduje sama jego forma, którą Kant określa mianem celowości bez celu, tzn. celowości, która nie ma dla podmiotu żadnej wartości praktycznej, np. nie prowadzi do poznania. Jednocześnie sąd smaku mówi raczej o właściwościach podmiotu niż przedmiotu, jego fundamen-

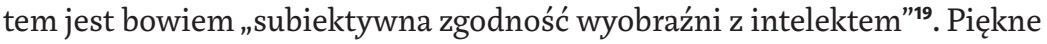
jest również to, w czym podmiot może dostrzec jedność w różnorodności. Jednak, jak słusznie zauważa Elaine P. Miller, ta jedność, poczucie ciąłości i całościowości, które odnajdujemy w kontakcie z przyrodą, to, zgodnie z Kantem, coś sztucznego, ponieważ nie wynika z empirycznego doświadczenia, ale z ludzkiej projekcji na kontemplowaną rzeczywistośćco . Jak zauważa badaczka, według Kanta estetyka musi opierać się na naturze jako totalności „samej w sobie”, chociaż obiektywnie, z perspektywy wiedzy nie jest to możliwe ${ }^{21}$ :

Natura sama w sobie nie jest piękna [...], ale staje się taka dzięki fantazjom, które ludzie tworzą na jej temat. [...] Nasze upodobanie do piękna natury jest w dużej mierze skonstruowane na bazie fantazji, w które ją ubieramy. Z odległości postrzegamy naturę jako żywą, ożywioną,

„)ej widok kompletnie go poraził. Wprawdzie już wcześniej, w czasie wizyty w jej mieszkaniu, przypadkiem zobaczył ją nago, ale tym razem zupełnie rozczuliło go jej posłusznie leżące ciało, które było dla niego uosobieniem efemerycznego piękna. Czułsię wzruszony do łez, patrząc na jej wychudłe obojczyki, płaskie jak u chłopca piersi, wystające żebra, niewinnie rozchylone uda i pozbawioną emocji twarz [...]"; tamże, s. 78-79. 
nieustannie rosnącą, ale w rzeczywistości są to wartości ludzkiej kreatywności, które projektujemy na „naturę” jako „fałszywą" całość. ${ }^{22}$

Piękno w naturze jest więc zawsze narzucaną jej przez podmiot fikcją. Zgodnie z Kantowską wykładnią mąż In-hye dostrzega w pięknie roślin własne o nich wyobrażenie, po czym reprojektuje je na Yong-hye. Realistyczne malunki kwiatów mają za zadanie „uzupełnić” jej nagie ciało wyobrażeniem artysty, ponieważ Yong-hye sama w sobie, bez fascynacji i artystycznej wizji szwagra, jest niczym, nic nie znaczy. Mężczyzna wymusza jednak na jej ciele znaczenia, czyni z niego symbol piękna, natury i zmysłowości. Mężczyzny nie interesuje realna Yong-hye i w pewnym sensie to, jak jej doświadcza, nie jest doświadczeniem empirycznym - seks stanowi jedynie zwieńczenie fantazji. Cała historia służy właściwie tylko potwierdzeniu wartości mężczyzny jako artysty, który jest w stanie poświęcić wszystko w imię wizji - nawet (a może zwłaszcza?) rzeczywistość. Tym samym dokonuje on niejako podwójnego aktu przemocy: z jednej strony wykorzystuje Yong-hye, tworząc z niej dzieło sztuki, płótno dla własnego - estetycznego i seksualnego - pożądania, estetyzując jej realne cierpienie i potwierdzając społeczny status jako uprzedmiotowionej kobiety; z drugiej strony natomiast dokonuje przemocy na samej naturze, na „roślinnej organiczności” Yong-hye, poświadczając fikcyjny charakter przyrody oraz jej uprzedmiotowienie przez człowieka. Czy więc praca artysty, zamiast być narzędziem emancypacji ciała, nieheteronormatywnej seksualności i nie-ludzkiego bycia, w ostateczności nie okazuje się kolejną metaforą patriarchalnej przemocy?

\section{Fotosynteza - bycie-rośliną jako forma podmiotowości}

Jednak, na co zwraca uwagę Michael Marder w Plant-Thinking, teoria estetyczna Kanta ma swoją drugą stronę. Jej założenia pomagają uniknąć esencjalizacji i ontologizacji natury - organicznego, „wegetatywnego życia” ${ }^{23}$. Kwiat u Kanta jest zwolniony z wszelkiej użyteczności i konieczności, jest uosobieniem celowości bez celu i jako taki nie wpisuje się ani w opozycję naturalny - sztuczny, ani podmiot - przedmiot. Dla człowieka jawi się jako piękny, ale jest to jedynie konsekwencja jego niejasnego ontologicznie statusu i piękno nie odbiera mu wolności:

22 Tamże, s. 26.

23 M. Marder Plant-Thinking, s. 140. 
Rzeczywisty kwiat nie reprezentuje już po prostu przejściowego etapu [w cyklu roślinnego życia], w którym [...] wskazuje ponad siebie na wyższy cel (np. owoc) albo gatunek, do którego przynależy. Na skraju nie-bycia, przemijając bądź więdnąc, zaczyna znaczyć jedynie siebie. ${ }^{24}$

Kwiat, nawet jeśli stanowi tylko przejściowy etap wegetatywnego cyklu, wciąż pozostaje czymś więcej. To „więcej” nie jest jednak naddatkiem sensu ani nawet piękna, ponieważ kwiat jako taki nie znaczy nic. Nie potrzebuje tożsamości, jest „niewyrażalny, nieokreślony, bez formy”25.

W tej perspektywie namalowane kwiaty nie nadają Yong-hye żadnej nowej tożsamości, a jednak są konieczne - pieczętują jej nowy rytm życia. Dzięki nim, Yong-hye przestaje śnić koszmary, jakby jej przemiana właśnie się dokonała.

- Nigdy nie jest taka sama... Czasem wydaje się bardzo znajoma, a czasem zupełnie obca, jak twarz, której nigdy wcześniej nie widziałam. Zdarza się, że jest cała zakrwawiona... Albo też przypomina gnijącego trupa. Uniósł opadające ze zmęczenia powieki i spojrzał jej w oczy. Mimo że już świtało, biegały niespokojnie, jak gdyby wcale nie była zmęczona.

- Myślałam, że to wszystko z powodu mięsa - ciągnęła. - Myślałam, że jeśli nie będę go jeść, to twarz przestanie się pojawiać. Ale to nic nie dało. Pomyślał, że powinien skupić się na jej słowach, ale niezależnie od jego woli jego oczy coraz bardziej się kleiły.

- Tak czy inaczej, teraz już wiem. Wiem, że to moja własna twarz. Twarz, która wyłania się z mojego brzucha. ${ }^{26}$

W wielości i różnorodności twarzy ze snu Yong-hye rozpoznaje samą siebie, co paradoksalnie wcale nie oznacza, że udaje jej się ponownie uchwycić własną tożsamość. Człowiek o wielu twarzach nie jest sobą, nie jest z sobą tożsamy. Ta wielość przywodzi na myśl raczej wielość właściwą właśnie roślinie, która, choć czasem postrzegana jako jedna, nigdy jedna nie jest, zawsze jest nagromadzeniem istnienn ${ }^{27}$. Tożsamość przestaje mieć tu znaczenie,

\footnotetext{
24 Tamże, s. 143, tłum. własne.

25 Tamże, s. 123.

26 H. Kang Wegetarianka, s. 105-106.

27 M. Marder Plant-Thinking, s. 68.
} 
podobnie jak własna twarz, która „wyłania się z brzucha”, nie jest więc już umiejscowiona na piedestale, ale gdzieś po środku, co zrównuje jej wartość z całą resztą ciała, pozbawia ją właściwej jej symboliki.

Jak pisze Marder, „roślinomyślenie [plant-thinking] zaczyna się wraz z rozpadem tożsamości" ${ }^{28}$. W rzeczywistości kwiaty na ciele Yong-hye, tak jak u Kanta, nie znaczą nic poza sobą, są całkowicie zwolnione z łańcucha celów, z podmiotowo-przedmiotowych zależności, i potwierdzają bycie Yong-hye jako bycie organizmu. Yong-hye, podobnie jak roślina, staje się bytem całkowicie płytkim i powierzchownym. Według Mardera „w sensie metafizycznym życie wegetatywne jest obiektywnie płaskie, ponieważ nie szczyci się żadną głęboką esencją, ponieważ roślina może wirtualnie odrzucić każdą ze swych części i nie odczuć straty" ${ }^{29}$. Nowa roślinna „podmiotowość” w rzeczywistości wcale podmiotowością nie jest, stanowi nową formę bycia, bycia w procesie, które niczego nie waloryzuje, do niczego nie dąży, ale też nie jest zależne od żadnych fantazmatycznych struktur.

Artystyczny eksperyment zostaje w końcu przerwany przez, zdawałoby się, najbardziej zdroworozsądkową osobę w całej rodzinie, czyli In-hye, żonę artysty i siostrę Yong-hye; kobieta doprowadza do rozwodu z niezrównoważonym mężem oraz do trwałej hospitalizacji siostry, zdiagnozowanej przez lekarzy jako schizofreniczka z jadłowstrętem. Jednak In-hye, chociaż, w przeciwieństwie do swojej siostry, stara się działać słusznie i ulegać otoczeniu, uznając porządek społeczny za priorytet, w rzeczywistości czuje się rozdarta, pusta i martwa, przestaje wierzyć w otaczającą ją rzeczywistość. Słowa jej siostry: „Dlaczego uważasz, że śmierć to, coś złego?"30, bezustannie do niej powracają. Być może gdyby nie posiadała dziecka, sama popadłaby w szaleństwo, sama przeistoczyłaby się w roślinę, czego potencjalność wyraża być może polip wyrosły w jej waginie. W odróżnieniu od męskich bohaterów powieści In-hye jest świadoma własnego wyalienowania i samotności, przez co jej narracja unika fantazmatyczności i otwiera się powoli na cierpienie siostry. 
Chociaż w Fotosyntezie, ostatniej części, to Yong-hye zostaje zamknięta w szpitalu psychiatrycznym, w rzeczywistości również In-hye ukazuje się czytelniczce jako kobieta zamknięta i, paradoksalnie, nawet bardziej zniewolona niż główna bohaterka. Kontrast między strukturą społeczną, zmuszającą ludzi do odgrywania wykreowanych sztucznie ról, a realnym, roślinnym byciem Yong-hye jest w tej części najsilniejszy. Choć początkowo In-hye nie chce się z tym pogodzić, ostatecznie, jako kobieta skrzywdzona, gwałcona, zmuszana do uległości, staje po stronie siostry i sprzeciwia się przemocy lekarzy, którzy próbują zmusić Yong-hye do przyjęcia pokarmu. In-hye stopniowo uświadamia sobie to, co dla siostry od dawna jest już wiadome. I podczas gdy ona zmaga się z wymuszonymi na niej zobowiązaniami, Yong-hye powoli kończy swoją ludzką egzystencję. Próbuje uciekać ze szpitala do lasu, gdzie czuje się sobą czy też raczej - przestaje czuć się czymkolwiek. Staje na rękach, zapuszczając dłonie-korzenie w ziemię i rozszerzając nogi, czekając aż z jej krocza zaczną wyrastać gałęzie. Mimo że wszyscy dokoła jej to wmawiają, wie, że nie cierpi na żadne zaburzenie psychiczne, ponieważ rośliny nie mogą oszaleć.

\section{Zakończenie}

Yong-hye wyzwala się ostatecznie z osaczającej ją rzeczywistości. Bycie-rośliną zwolnione jest z zasad binarnie pojmowanej seksualnej różnicy i opowiada się za seksualnością rozproszoną, perwersyjną, nie-reprodukcyjną ${ }^{31}$. Czytelniczka może uznać to za odpowiedź Han Kang na stwierdzenie przez Joannę Elfving-Hwang, że w ramach koreańskiej struktury społecznej kobiety nie są w stanie przekroczyć własnego statusu z powodu braku jakichkolwiek pozytywnych przedstawień kobiecej seksualności; kobieta skazana jest na esencjalistycznie pojmowaną kobiecość, ponieważ wszelka aktywna seksualność jest z miejsca uznawana za dewiację ${ }^{32}$. Tam, gdzie panuje patriarchalny porządek symboliczny, nie ma miejsca na żadne pozytywnie rozumiane bycie kobietą ${ }^{33}$. Dlatego Yong-hye kobietą być przestaje, uciekając z nadanego jej porządku w bycie-rośliną. W ramach własnej ontologii roślina „nie przyjmuje opozycyjnej postawy wobec

M. Marder Plant-Thinking, s. 86. 
swojego otoczenia"34. Roślina wyłamuje się z podziałów na męskie i kobiece, aktywne czy pasywne ${ }^{35}$. Nie jest ani podmiotem, ani przedmiotem. Jest zawsze na marginesie. Wreszcie, jest gdzieś między życiem i śmiercią; jest obojętna wobec śmierci, ponieważ w swojej wielości, będąc naraz korzeniem, liściem, kwiatem, owocem i nasieniem, uczestniczy w śmierci cały czas. A jednocześnie pozostaje żywotnością samą, wznosząc się w tym samym czasie ku słońcu i schodząc głęboko w ziemię, ku życiu i śmierci zarazem $^{36}$.

W swojej książce Elfving-Hwang stawia tezę, że podstawową trudnością realistycznej prozy koreańskiej jest jej silne uwikłanie w panujący porządek symboliczny, przez co pisarkom ciężko uciec od zadomowionych w kulturze religijnych, mitycznych i archetypicznych wyobrażeń kobiecości. Z tego powodu proza fantastyczna, która podważa zasady zastanej rzeczywistości, może stać się istotną przestrzenią rekonstruowania tych schematów ${ }^{37}$. Dlatego, jeśli nie będziemy traktować Wegetarianki, wbrew temu, co sugeruje nam troje narratorów, jako powieści realistycznej, w której główna bohaterka popada w szaleństwo, możemy dostrzec inną, mniej „racjonalną" perspektywę. Jak zauważa Elfving-Hwang, , jedyny «autentyczny» wyraz kobiecości może zostać odnaleziony w tym, co męskość odrzuca jako nadmiar"38. Przemiana Yong-hye jest zatem właśnie tym nadmiarem, który w ramach panującego porządku członkowie jej rodziny próbują skategoryzować jako szaleństwo. Jeśli jednak uznamy ów nadmiar jako taki, okaże się być może, że Yong-hye udaje się uciec społeczeństwu i stworzyć alternatywną formę bycia kobietą. Alternatywa ta jest jednak radykalna: być kobietą poza patriarchatem oznacza tu porzucenie nie tylko kobiecości, ale i ludzkiej kondycji w ogóle. Pamiętać należy jednak, że w powieści to, co ludzkie, jest tożsame z tym, co społeczne, patriarchalne i męskie. Ucieczka z tej struktury jest nie tylko propozycją wyzwolenia kobiety z jej kobiecości, ale po prostu propozycją alternatywnej struktury, która zamiast opierać się na metafizyce opozycji, zasadza się na różnorodności, wielości, na ontologii różnicy. W pewnym sensie ta alternatywna rzeczywistość w Wegetariance ukazuje się nie tylko

Tamże, s. 86.

Tamże, s. 69.

Tamże, s. 29.

J. Elfving-Hwang Representations of Feminity..., s. 165-167.

Tamże, s. 177. 
jako lepsza propozycja, ale również jako sposób walki z fantazmatycznym społeczeństwem, które zamiast pozostać blisko ziemi, ciała i realnego, więzi jednostki w sztucznych i alienujących rolach.

\section{Abstract}

\section{Zofia Jakubowicz-Prokop}

UNIVERSITY OFWARSAW

To Be a Woman or to Be a Plant? Forms of Subjectivity in Han Kang's The Vegetarian

Examining Han Kang's novel The Vegetarian, Jakubowicz-Prokop brings together two contextualizing perspectives, namely the position of women in Korean culture as seen mostly in contemporary literature, and the role of plants as presented in Western philosophy. The main goal of this article is to explain the protagonist's transformation as a process of becoming-a-plant - a process that presents the only possible form of freedom in a world of rigorous gender roles and a dualistic concept of reality. Becoming-a-plant is portrayed as a way of being that eludes the metaphysical tradition and presents an attempt to rethink the subject anew.

\section{Keywords}

Han Kang, The Vegetarian, Korea, aesthetics, plant, becoming 